\title{
NYOLC KÉRDÉS, KÉTSZER NYOLC VÁLASZ
}

\author{
CSIZMADIA ZSOLT, TAKÁCS SZABOLCS, VIZVÁRI BÉLA
}

\begin{abstract}
Cikkünk rendhagyó lesz, több szempontból is. Egyik oldalról igen kevés olyan dolgozat jelenik meg tudományos lapokban, mely nem a „problémafelvetés-hivatkozások-problémamegoldás-diszkusszió” négyes körforgásában értelmezhető. Másik oldalról szerettük volna, ha 70 év élet- és 50 év tanítási tapasztalata olyan környezetben jelenik meg, ahol az akadémiai kérdésfelvetések ipari, alkalmazási vetületei is felszínre kerülnek. Valamint mindez egy kötetlenebb, de mégis némileg strukturált beszélgetés leirataként láthat napvilágot. Bízunk abban, hogy esetleg vitákat generálhatunk ezzel a beszélgetéssel, vagy csak gondolatokat ébreszthetünk az utánunk jövő generáció tagjaiban. A beszélgetés fö résztvevői Vizvári Béla és Csizmadia Zsolt - Takács Szabolcs pedig a beszélgetés moderálásában és szövegezésében vett részt. A szerzőket éppen ezért alfabetikus sorrendben tüntettük fel.
\end{abstract}

\section{Bevezető}

A beszélgetés előtt megállapodtunk a kérdésekben, melyek jelenleg foglalkoztatják a beszélgetőtársakat. E kérdések a matematikai programozási, illetve optimalizálási feladatok megoldására vonatkoztak, és az alább olvashatók:

1. NP-teljesnek ígérkező modellek esetén meg kell-e állapítani az egzakt modell - heurisztikus módszer határát? Ez akadémiai kérdésfelvetésnek tűnik, de van gyakorlati jelentősége is.

2. Melyek az egzakt megoldás mellózésének és a csak heurisztikus megoldás alkalmazásának szakmailag korrekt feltételei?

3. Lehet-e használni az időben levágott korlátozást és szétválasztást heurisztikaként? Általánosságban: ha heurisztikákat használunk, akkor globális és nem globális heurisztikák eredményeit miként hasonlíthatjuk össze? Talán még általánosabban (kicsit szabadabban értelmezve) hogyan értékeljük, ha egy megoldó hamar ad jó megoldást (majd sokáig bizonyítja, hogy nincsen jobb), szemben azzal, ha a végén ad egy optimálisat? 
4. Honnan vegyünk hiteles tesztfeladatokat?

5. A megoldások minősége különböző lehet a toleranciáktól és a feladat numerikus nehézségétől függöen. Ezeket figyelembe tudjuk venni?

6. Az átlagszámításnál hogyan kezeljük a kiugró értékeket? Mitől nem fogja az eredményeket néhány kiugró adat dominálni?

7. Mennyire lehet/kell a felhasználó előzetes ismereteit a problémáról egy professzionális szoftverrel közölni?

8. Ha van beállított megengedett időkorlát, lehet-e az eredményeket befolyásolni ennek ügyes megválasztásával? És mit lehet tenni ez ellen? Kell-e tenni ellene valamit, vagy egyszerűen csak „mindenféle időkorlátra” adjunk át információt?

E nyolc kérdésben kértem ki beszélgetőpartnereim véleményét, meglátásait, tapasztalatait. Most a válaszok következzenek úgy, ahogy azok a beszélgetés során elhangoztak.

\section{NP-teljesség: egzaktság, heurisztikák, határok}

$\boldsymbol{V} . \boldsymbol{B}$. : Ha megengeditek, akkor kezdem én, mert én vetettem fel ezt a kérdést. Mostanában több olyan cikket is kaptam bírálatra, amely két részből állt, és e két résznek semmifajta köze nem volt egymáshoz.

A szerzők felvetettek egy problémát - ami nem matematikai, hanem alkalmazott probléma. A probléma modelljéről azt mondták, hogy ez egy egész értékü probléma, tehát akkor NP-teljes, nem tudjuk megoldani. Ekkor következik a cikk második része, egy heurisztikus eljárás, amivel megoldanak valamit, és ez önmagában akár teljesen korrekt is lehet. Azonban ennek a heurisztikának általában nincsen semmi köze az eredeti problémához, de megoldanak valamit - és a lefutás után értékelik a megoldást. Ez a szerzők szerint egy jó cikk - szerintem viszont nem az. Mert a két résznek így nincsen köze egymáshoz.

Először is igazolni kellene, hogy a mi feladatunk (az a feladatosztály) speciel tényleg NP-teljes. Igazuk van abban, hogy általában az - de ezt akkor is bizonyítani kellene. Utána viszont kellene tudni azt is, hogy az adott feladatosztályt milyen méretig tudjuk megoldani.

Lehet persze innentől arról beszélni, hogy az adott feladatosztályból ez milyen struktúrájú? Mit teszi nehézzé vagy könnyüvé? Tudok rá két példát is mondani.

Ösidőkben, amikor még Zsolt diák volt...

$\boldsymbol{T} . \boldsymbol{S z}$.: Mintha mi együtt lettünk volna diákok Zsolttal?

$\boldsymbol{V}$.B.: Zsolt 300 éve volt diák, én 500 éve voltam diák. Szóval, Zsolt, ha emlékszel rá, akkor Földes Pistával dolgoztunk egy problémán, amit nagyon nehezen 
oldogattunk. Volt egy modell, amihez hozzávettünk több ezer, teljesen felesleges feltételt. Így viszont már pillanatok alatt meg tudtuk oldani. Ez egy érdekes tapasztalat volt.

De tudnék egy példát mondani Zsolt jelenlegi munkahelyéről is. Oldogattam egy nagy feladatot a megoldótok egy régi verziójával - több ezer részfeladaton keresztül, amiket dokumentáltam is. Majd a valóban jóindulatú főnököd javasolta, hogy alkalmazzam az új változatot. Ezen a speciális feladaton azonban lényegesen lassabb volt, mint a régi változat. Úgy általában bizonyosan jobb volt, gyorsabb volt - de speciel ennél a feladatnál ez nem volt igaz.

És ha visszaélhetek az időtökkel, akkor még régebben, amikor Ti még diákok sem voltatok, a Bilkenten voltam, ahol egy Ramazan Demir nevü hallgatóval dolgoztunk együtt párhuzamos, egyforma berendezések ütemezésén. A feladatok generálásában volt csak különbség. Volt olyan feladatosztály, ahol 800 ezer, tehát majdnem egymillió munkát tudtunk úgy ütemezni, hogy megkaptuk az optimális megoldást a módszerünkkel.

Volt olyan osztály is, ahol 50-et tudtunk, 60-at nem (az előbb majdnem egy millióról beszéltem) és látszott, hogy 55-nél történik valami, utána nem tudunk dolgozni.

Van tehát olyan, amikor a megoldó jól passzol a feladathoz, és akkor igen nagy méretü feladatokat is meg tudunk oldani - más esetekben pedig esélyünk sincsen.

Cs.Zs.: Megjegyezném, hogy az NP-teljes feladatok esetében a méret lényegében semmit sem mond. Vannak olyan feladatok, ahol egészen kis problémák is nagyon nehezek akár csak 40-50 változóval, ami nem megoldható - más esetekben pedig igen nagy méretben is jól tudunk dolgozni.

Más esetben pedig illeszkedik a szolverhez - ez gyakran annyit jelent, hogy a szolver fejlesztői láttak már olyan feladatot - és gond nélkül megoldható.

Én például az alábbit javasolom: elsősorban meg kell nézni, mi a feladat struktúrája. Majd oda kell adni az elérhető szolvereknek (ez az akadémiai térben járható út, mert a nagy szolvereknek van akadémiai licensze), és ki kell próbálni őket. Lehetőleg e próbákat nem véletlen számokon alapuló feladathalmazon kell megtenni - és ezek után lehet dönteni.

\section{Egzaktság és heurisztika - mik az alkalmazás korrekt feltételei?}

$\boldsymbol{T} . \boldsymbol{S z}$.: Ezzel rá is tértünk akkor a második kérdéskörre? Úgy érzed, érted, hogy akkor egy kellő feladathalmazon érdemes, kell kipróbálni a feladataidat és azon kell jónak lenni?

Cs.Zs.: Ez egy bevett szokás. Azonban fontos kiemelni azt, ha egy adott speciális feladaton a heurisztikád jó, illetve van olyan jó, mint a nagy szolverek, akkor az igenis jó eredmény! Ugyanis a szolverek mögött jelentős erőforrások állnak - tehát legalább olyan jót elérni nem egy lebecsülendő eredmény! Az valóban lehet, ha ezt utána elküldöd a fejlesztőknek, akkor azt beépítik, és a speciális osztályon 
is már jól, vagy jobban fognak dolgozni. De mindenképpen fontos, ha hozod azt, amit a szolver hoz, az már egy figyelemre méltó eredmény - még speciális feladaton is.

Ha a szolvert jól beállítod, visszajöhetnek egy olyan finomhangolással, ami még a tiednél is jobb. De nem ez a cél, nem erről szól az egész, hanem arról, hogy a te heurisztikád jó, hatékony.

A te lépéselőnyöd az, hogy láttad a feladatot - a szolver előnye a több évnyi belefektetett fejlesztési tapasztalat. Én azt mondanám, ha a te heurisztikád jó vagy jobb, mint a szolver, és ezzel a megbízó elégedett, akkor rendben van. A szolvernek a feladat alkalmazóját kell kiszolgálnia.

Általánosan a nagy méret, a nem konvex feladatok esetében a heurisztikák általában elfogadottak, van létjogosultságuk. Vagy ha olyan feladatosztályba futunk bele, amire nincsen algoritmus.

T.Sz.: Béla?

$\boldsymbol{V} . \boldsymbol{B . :}$ Én ezzel teljesen egyetértek.

Cs.Zs.: Fontos még az is, hogy a szolver-fejlesztőket az szokta inspirálni, ha a tesztfeladatok egy mindenki által elérhető felületen vannak - mert akkor mindenki tudja ezt tesztelni, mindenki tudja tesztelésre használni. Ebből következően még inkább transzparenssé válik, hogy ki teljesít jobban/rosszabbul.

\section{Időben levágott korlátozás és szétválasztás? Globális és nem globális megoldók összehasonlítása. Sőt: gyorsan majdnem jót, vagy lassan jobbat?}

Cs.Zs.: Ezt most kezdeném én: az első olyannyira lehet, hogy lényegében minden szolver rutinból csinálja. Ez egy tipikus heurisztika: van egy megoldás, ott van egy környezet, amiben ez müködik - és ott dolgozom valamennyit tovább.

Az időben levágással az a gond, hogy determinisztikus módon kell levágni a feladatot, hiszen ideálisan ismételhetőnek kell lennie, vagyis ez lehet idő, de inkább iterációszám vagy egyéb determinisztikus mennyiség, amiben limitáljuk a „korlátozás és szétválasztás” módszerét.

Az összehasonlítás számunkra is gond volt, mert az Akadémia szereti azt gondolni, hogy mindig globális megoldókkal dolgoznak és hasonlítják össze - de ez nem egészen igazságos akkor, ha heurisztikák vannak, mert lokális megoldásokat érnek el a szolverek más és más idők alatt. Így maga a heurisztika összehasonlítása nem lesz egészen igazságos.

Ha fejlesztesz, akkor kérdés az, hogy például egy új módszer mikor jobb, mikor rosszabb? Erre kitaláltunk egy új módszert, ami a primál-integrál elvén alapul [1].

Az egészértékü megoldóknak van egy „GAP” mértéke. Ez azt jelenti, hogy mennyire igazolt az, hogy a jelenlegi megoldás optimális. Ha van egy megoldás, aminek a jelenlegi megoldása 100, és a GAP 20\%, akkor az azt jelenti, hogy az optimum valahol 80 és 120 között van. 
Az ötlet: a GAP függvényt integráljuk az időben. Ez azt jelenti, hogy ha megoldásunk van az elején - akkor az lenyomja a GAP-et (míg ha nincsen megoldás, csak a végén, akkor a GAP végig azonos marad). Ez azt eredményezi, hogy „boldogabb vagy" az eredményeddel az elején, mintha csak a végén van megoldás.

Ez nagyjából a primál-duál integrál, hiszen itt van egy korlátunk is a duál oldalról.

Heurisztika esetében azért nem müködik így ez az integrál, mert nincsen duál korlátunk - és a legjobb megoldást sem ismerjük. Viszont az az ötlet, hogy ha van két megoldásunk, akkor a jobbik megoldás mint korlát már müködik - ha több ilyen megoldás van, akkor a legjobbja szintén jó korlát.

Amit sikerült bizonyítani [3]:

1. Az új megoldások számadataiból az új integrálok jól, gyorsan számolhatók tehát újabb és újabb megoldásokkal könnyű update-et csinálni erre a mértékre.

2. Szintén lehetett bizonyítani, hogy ez a mérték tranzitív, tehát a különböző megoldásokon rendes rendezést lehet adni.

Érdemes azt is megemlíteni, egy lokális szolver heurisztikaként is felfogható. Ezen vita van, de mi azt mondtuk, hogy a lokális szolver bizonyos feltételek teljesülése mellett igazolja, hogy lokális optimumban van - míg a heurisztika egyszerúen csak egy jó megoldást akar adni.

$\boldsymbol{V}$.B.: Nekem nagy bánatom volt a régebbi szolvereknél, hogy nem tudtam megadni célfüggvény értékeket. Ha ezt meg tudtam volna tenni, akkor az nagyban könnyítette volna a dolgomat.

Akkoriban kitaláltam egy függvényt, ami megmutatta, hogy a szolver az én feladatomra miként haladt az optimum felé - és elég jól tudtam jósolni a segítségével.

Cs.Zs.: Az szép teljesítmény, mert ilyet általában nem tudunk mondani.

$\boldsymbol{V} . \boldsymbol{B} .:$ Az én feladatomra, specifikusan tudtam ezt megmondani és megmutatni.

Ha most teljesen alkalmazás szinten dolgozom, és nem akadémiai szinten, akkor alapvetően két feladattípust érdemes megkülönböztetni.

Az egyik feladattípus az, amikor megoldjuk a feladatot, és annak eredményét sokáig vagy sokat fogjuk használni:

1. Egy kórházban a kórházi osztályok elhelyezése.

2. Egy autógyárban a gyártósor beállítása.

Időben vagy darabszámban nagyon sokáig úgy használjuk a rendszert, ahogy megcsináltuk. Ezek beruházási feladatok, ilyenkor az optimalizálásba érdemes sok időt, akár heteket is belefektetni. 
Ezzel szemben vannak olyan feladatok, amik nem ilyenek. Most humanitárius logisztikával foglalkozom. Itt például egy földrengés esetében az, hogy a most visszaérkező mentőautó merre menjen tovább, nem tervezhető napokig. Azonnal irányítanom kell, nincsen tere az optimalizálási időnek.

Ez a két feladatcsoport felhasználási szempontból igen különböző. Mindkettő mögött igen bonyolult modellek is lehetnek.

Cs.Zs.: Mi ezeket offline és online eljárásoknak nevezzük.

$\boldsymbol{V}$.B.: Ez rendben van, és a második esetben nem tudok érvelni a heurisztikákkal szemben - ha azok elfogadható megoldásokat adnak, akkor részemről rendben vannak.

\section{Hiteles tesztfeladatok}

$\boldsymbol{V}$.B.: Ezt kezdeném én, mert erre majd Zsolt sok okosat tud mondani.

Amikor én ifjú voltam és bohó, akkor ha olvastunk egy cikket és a tesztfeladatokat elkértük, akkor ezek a legnagyobb titkoknak számítottak. Alig lehetett tesztfeladatot kapni. És ne felejtsétek el, én 500 éve voltam diák.

Egy nyomtatott áramköri lapon a valóságban van 100-150 elem. Eredetileg Zsolt ötlete volt, hogy ha egy olyan automata van, amiben pici cellákban van az alkatrész tárolva, akkor egy két részes gráfban való mozgás írja le a cellák feltöltését és a robot mozgását. Ha 120 cella van, akkor 240 városos utazó ügynök feladat van, amit öt iterációban meg tudtunk oldani. Viszont nem biztos, hogy ilyen feladatot mi egy teszt adatbázisban kaphatunk.

Cs.Zs.: Igen. Azt hallhattuk már, hogy vannak most már nyilvános feladatgyüjtemények. Ezek minősége nagyban függ attól, hogy milyen társaság van a feladatbank mögött.

Például a legismertebb egészértékű feladatgyüjtemény mögött több hónapos munkája van egy 15-16 fós társaságnak, hogy ott jó feladatok legyenek. Söt maga a végső kiválogatás is egy egészértékü feladatként volt megfogalmazva (kézi válogatás után)[2].

Vannak olyanok is, ahol jó feladatok vannak, de inkább Akadémiából jövő feladatok, és elég messze vannak az ipari feladatoktól.

Amit én látok, hogy nagyon sok olyan példa van, amik véletlen számokkal generált feladatok. Ezek nem jók, ezek általában vagy sokkal könnyebbek, vagy éppen sokkal nehezebbek, mint a való élet feladatai. Illetve hiba az is, ha a tesztfeladatok nem nyilvánosak, ezeket ki kell adni. Ezzel lehet ugyanis azt kivédeni, hogy generálunk 100 ezer feladatot, és az a 10 lesz a teszt, amely 10 darabon megvertem a szolvert. Ez nem igazságos, ezért kell nyilvánosságra hozni a feladatokat, amikkel dolgozunk. 


\section{Minőség kérdése tolerancia, nehézség és idő figyelembe vételével}

Cs.Zs.: Az összes szigorúan vett tesztfeladatnál általános elvárás az, hogy azokat, ahol a numerikus hibák a feladat sajátjai, azokat a feladatokat törölni érdemes. Ezen azt értjük, hogy ne azt nézzük meg, hogy egy szolver szerencsés módon elkerüli a numerikus nehézségeket (nagy számok vagy igen kis számok).

$\boldsymbol{V} . \boldsymbol{B}$. : Fejtsük ezt ki egy kicsit, mert szerintem az olvasó sem fogja ezt egészen érteni.

Cs.Zs.: Mondom az egyszerüen felismerhető dolgot. Ha egy feladatban nagy számok vannak, akkor ez két helyen rögtön gondot fog okozni. Az elején lévő skálázás valószínúleg el fogja tüntetni a nagy számokat - de ez gondot is jelenthet, mert „kis” számok jelennek meg, és ezek a struktúrális elemek utána nem különülnek el a kerekítési, illetve numerikus hibáktól.

A másik gond az, hogy a numerikusan nagy számok elnyelhetnek kisebb számokat (ami a szokásos dupla pontosságú számok nagyságrendje felett van). A numerikus nehézséget tehát el kell különíteni a struktúrális részektől.

Mondok egy másik példát: nagyon sok feladatnak van egymásba ágyazott struktúrája. Ezt azonban igen nehéz észrevenni a gép számára - lényegében tudni kell, hogy mit is keresünk. Viszont ezek a halmozott viselkedések (feladatok a feladatokban) azt eredményezhetik, hogy habár lokálisan minden lépés jónak tünik, összességében mégis baj van, legegyszerübben például ha egy számsorban minden szám az előző duplája.

A szolver előbb-utóbb észreveszi, hogy gond van, és ilyenkor le is állítja a folyamatot, vagy legalábbis valamit közbeszól. De ez egy ad hoc döntés lesz, ami egy ilyen feladaton egyszer jó, más számoknál meg rosszabb eredményre vezet. Ezeket a szerencsés egybeeséseket szeretnénk kiszürni, mert ezek nem szisztematikus eredményt adnak, ezek a feladatok tesztelésere nem megfelelőek.

\section{6. Átlagszámítás és kiugró értékek - hogyan hasonlítsunk össze? Van helyette más mutató?}

Cs.Zs.: Ezen az egész értékü közösség elég sok időt eltöltött. Általános az, hogy nem használunk aritmetikai átlagot, mert nem szerencsés.

Helyette sokszor használt a geometriai közép, mert jól lehet magyarázni, a másik megközelítés az, hogy minden megoldáshoz adunk egy konstans értéket (mondjuk 10-et), ami egyik oldalról jól szüri a „mázlit” - szerencsésen gyors megoldás, másik oldalról viszont jól kezeli a „fix költségek” irányát is, amit bármely feladatnál meg lehet azért érteni.

$\boldsymbol{V} . \boldsymbol{B}$.: Én annyit még hozzátennék, hogy offline esetekben akár az összes megoldót végignézném. Hiszen offline esetben erre van idő, van lehetőség, van mód.

$\boldsymbol{T} . \boldsymbol{S z}$.: Én alapvetően inkább statisztikai oldalról közelítenék: nagyon kevés olyan esetet tudok elképzelni, amikor az aritmetikai közép egy jó mutató. A rend- 
szerek döntő többségében én nem találom egy jó, alkalmazott középértéknek. Nagyon érzékeny, egy-egy érték elmozgathatja - szinte bármilyen más választás jobb. Trimmelhetem, súlyozhatom - de ezt én nem látom értelmesnek. Szerintem okosabb azt a kérdést feltenni, hogy mire is vagyunk kíváncsiak? Mit akarunk igazán? A legjobb időt, a legrosszabb esetek idejét - mi érdekel igazán minket az össszehasonlításnál.

Cs.Zs.: Itt most egy sorrendet akarunk a szolverek között.

$\boldsymbol{T} . \boldsymbol{S z}$.: Mondok egy egyszerü példát. Bélával ugyanazon középiskolába jártunk, de vélhetően nem ugyanaz volt a testnevelö tanárunk.

$\boldsymbol{V}$.B.: Nő volt?

$\boldsymbol{T} . \boldsymbol{S} \boldsymbol{z}$.: Nem, férfi volt.

$\boldsymbol{V}$.B.: Akkor nem ugyanaz volt.

T.Sz.: Mondom akkor a példát: tegyük fel, hogy a középiskolai testnevelő tanárom egy futóversenyt rendez egy sportgimnáziummal. A mi osztályunkban van 29 átlagosnak mondható diák és jómagam, aki egy métert nem fogok futni. A sportgimnáziumban van 27 atléta és három szumó birkózó. A Margitszigeten köröket futva azt a stratégiát választjuk, hogy a sportgimisek loholnak, én pedig a teljes négy év osztálypénzével megállok a három szumóssal az első talponállóban és fizetek. Ekkor a sportgimisek átlagát három szumós fogja rontani és a miénket csak én. Ezzel az átlagok szintjén nyerni fogunk.

De ha helyette azt csináljuk, hogy párokba rendezzük a diákokat és megnézzük, hogy páros versenyeken ki nyer többet, akkor már látható, hogy nehezen verjük meg a sportgimiseket. Ugyanis az ő atlétáik mindig nyernek, mi pedig csak akkor, ha szumóst választunk (és közülünk nem én futok). Ez egy merőben más mérték lenne, mint az átlagok.

\section{Felhasználó előzetes ismereteinek beépítése, alkalmazása}

Cs.Zs.: Ez feltétlenül kell! Minél több információt képes a szolver befogadni, annál jobb. Egy induló megoldás megadása drasztikusan javíthat. Akár egészértékü, akár nemlineáris feladatoknál fontos, hogy a felhasználó ad-e számunkra egy kiindulási pontot.

Fontos kiemelni még valamit: az ügyfél általában azért elégedett a lokális szolverrel, mert a legtöbb gyakorlati felhasználó pontosan tudja, hogy mit keres! Sok, nagyon sok feladatot láttak, tehát „sejtik” a megoldást és tudják, hogy mit keresnek.

$\boldsymbol{V} . \boldsymbol{B}$.: Zsolt, ezek mennyire mérnöki, müszaki feladatok?

Cs.Zs.: A személyes tapasztalatom az, hogy inkább azok.

$\boldsymbol{V}$.B.: Ezt vártam. Az én tapasztalatom ugyanis az, hogy a szervezés esetében a helyi szakemberek általában csőlátásúak, és lokális érdekeket vetítenek ki globális feltétellé. Ezzel szemben a müszaki irányok azt mutatják, hogy ott azért vannak globális, általános érvényü szabályok. 
$\boldsymbol{T} . \boldsymbol{S z}$.: Én valahogy kettős dolgot érzek ebben statisztikai alkalmazóként. Mert egyik oldalról van olyan, hogy a szakemberek általános meglátásai többnyire azért meg szoktak jelenni a számokban.

Viszont van egyfajta „bevásárló központ” hatás is a szakembereknél. Ezt én neveztem el, és az alábbit értem rajta: tegyük fel, hogy COVID miatt reggel 6-kor kinyitom a kapukat és beengedem azokat, akik ott vannak - majd beengedve őket, zárom a kapukat.

A pénztáraknál ülnek 10-en, de 10 perc után felállítok közülük nyolcat. A maradék két pénztáros azt fogja érzékelni, hogy egyre több a vevő.

Ez például akár orvosi, akár pszichológus praxisban úgy jelenik meg, hogy a praxis elején könnyű feladatok vannak - majd 20-30 év praxistapasztalat után azt látom, a világ egyre durvább, mert egyre több komoly betegség, probléma jelenik meg nálam - az egyszerü esetek pedig nem. Holott nem a világ durvul, hanem mi leszünk egyre tapasztaltabbak, és egyre bonyolultabb esetekkel találnak meg minket - mert a könnyü esetek maradnak a kezdőknél.

Cs.Zs.: Igen, és ez megjelenik egyéb iránt a tesztfeladatoknál is. Mert nem a mindennapos feladatokat küldik el általában a feladatbankoknak, hanem az érdekes eseteket. Ami általában azt jelenti, valamiért nehéz. Ez aztán odébb tolja az átlagot is és minden egyebet. Emiatt kell jól megválasztani a tesztfeladatokat.

\section{Beállított időkorlátok ügyes megválasztása - visszaélések kizárása}

Cs.Zs.: Ez részben a szumósok kizárását jelenti.

$\boldsymbol{T} . \boldsymbol{S z}$. : És akkor ezzel le is zárjuk?

Cs.Zs.: Azért nem, mondok rá még példákat. Egyik oldalról fontos látni, hogy nagy feladatokon egy lokális szolver bármilyen globális szolvert megver, mert egy globális szolver nem tudja megoldani a nagyon nagy feladatokat.

Másik oldalról az integrálos ötlet itt is megoldás lehet. Ugyanis egy értelmes kérdés az, hogy a felhasználó mennyire boldog akkor, ha fél óra alatt adok neki megoldást. Ezek után megkérdezem tőle, hogy ha vár 2-3 órát, akkor adok egy 10\%-kal jobbat. Ha vár egy napot, akkor még többet javítok, és így tovább.

Az integrált ezzel súlyozva - akár személyesen, rád szabva - kizárható egy csomó eset (például a szumósok esete).

$\boldsymbol{V}$.B.: Fontos, hogy ez nem csak olyan szempont lehet, ami az optimalizáláshoz kötődő szempont. Például, ha nem sietek, akkor mindegy, hogy fél óra vagy egy óra alatt számol valami - akkor sokszor kiléphetünk a matematika és számítástechnika világából. Én ugyanis döntőnek találom azt, hogy online vagy offline feladatról van szó, mert ez nem feltétlenül folytonos jelenség.

Mindegyiknek lehet értelme, de vannak olyan esetek, amikor ezen döntés nem az optimalizálási feladat része, hanem külső szempont, tehát nem is biztos, hogy van rá szabály. 
Cs.Zs.: Ez így van, de a szolverek összehasonlításánál azért egzakt korlátokat használhatunk, ezek pedig tipizálhatók.

$\boldsymbol{T} . \boldsymbol{S z}$.: Jól értem, hogy akkor ez akár egy-egy szolveren belüli heurisztikák összehasonlítására is használható?

$\boldsymbol{V}$.B.: Én más kérdést tennék fel Zsoltnak. Ti nem mondtok olyat a felhasználónak, hogy most ennyire közel vagyok a megoldáshoz, folytassam-e tovább?

Cs.Zs.: De, ilyet mondunk - ez egy megállítási kritérium alapvetően. Úgyhogy igen, ez egy létező felhasználói döntés lehet egy ilyen esetben.

$\boldsymbol{T} . \boldsymbol{S z}$.: Uraim! Én köszönöm a beszélgetést, azt hiszem végigvettük a kérdéseket, amiket előzetesen egyeztettünk.

\section{Befejezés}

A szerzők a beszélgetést részben a járvány, részben a földrajzi távolságok miatt a Ciprus-Anglia-Magyarország háromszögben folytatták le, 2020. november 14-én.

\section{Hivatkozások}

[1] Berthold, T.: Measuring the impact of primal heuristics. PhD Thesis.

[2] A. Gleixner, G. Hendel, G. Gamrath, T. Achterberg, M. Bastubbe, T. Berthold, P.M. Christophel, K. Jarck, T. Koch, J. Linderoth, M. Lübbecke, H.D. Mittelmann, D. Ozyurt, T.K. Ralphs, D. Salvagnin and Shinano, Y..: MIPLIB 2017: DataDriven Compilation of the 6th Mixed-Integer Programming Library. Mathematical Programming Computation, Vol. 13, pp. 443-490 (2021).

DOI: $10.1007 / \mathrm{s} 12532-020-00194-3$

[3] T. Berthold And Csizmadia, Zs.: The confined primal integral: a measure to benchmark heuristic MINLP solvers against global MINLP solvers.. Mathematical Programming Vol. 188, pp. 523-537 (2020). DOI: 10.1007/s10107-020-01547-5 


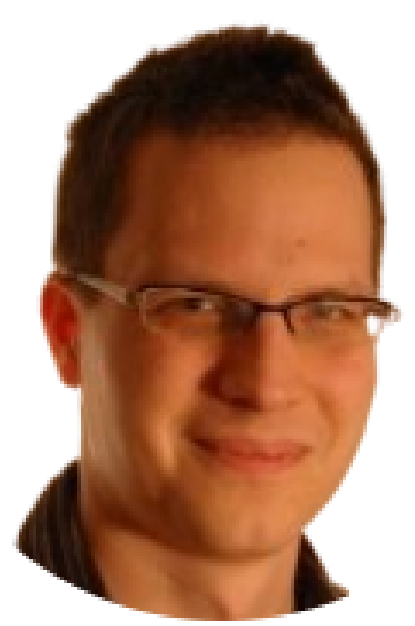

CSIZMADIA ZSOLT

FICO

zsolt.csizmadia@gmail.com

\section{TAKÁCS SZABOLCS}

Károli Gáspár Református Egyetem, BTK, Pszichológiai Intézet

takacs.szabolcs@kre.hu

\section{VIZVÁRI BÉLA}

Department of Industrial Engineering, Eastern Mediterranean University

Famagusta, Észak-Ciprus

bela.vizvari@emu.edu.tr

EIGHT QUESTIONS, EIGHT ANSWERS TWICE
Csizmadia Zsolt az ELTE-n szerzett doktori címet 2007-ben, majd ugyanazon évben felvették az Xpress megoldót készítő Dash Optimization (jelenleg FICO) fejlesztői csoportjába, ahol 2013 óta mint fómérnök (principal engineer) dolgozik. Elsősorban nagyméretü nemlineáris feladatok megoldásán dolgozik, de jelentős fejlesztői tapasztalattal rendelkezik az optimalizálási feladatok és módszerek legkülönbözőbb területein, beleértve a lineáris, kvadratikus és egészértékü optimalizálást és az azokkal való modellezést. A fejlesztés mellett számottevő szakértői tevékenységet végez elsősorban banki, pénzügyi, illetve mérnöki optimalizálási területeken.

\section{Zsolt Csizmadia, Szabolcs Takács, BÉla Vizvári}

Our article is unusual in several ways. On the one hand, to our best knowledge, very few publications appear in scientific journals that cannot be interpreted in one of the four circles of "problem raising-references-problem solving-discussion".

On the other hand, we wanted 70 years of life and 50 years of teaching experience to appear in an environment that combines the industrial and application aspects with academic values and points of views in the form of a casual, yet somewhat structured conversation.

We hope the conversation presented will generate discussions, or inspire thoughts in the members of the next generation. The main participants of the conversation were Béla Vizvári and Zsolt Csizmadia - Szabolcs Takács participated as the moderator and helped wording the conversation. The authors are therefore listed in alphabetical order. 